\title{
Effect of In situ Cultivation and Incorporation of Green Manure Crops on the Yield of Coconut
}

\author{
H. VIJAYARAGHAVAN* and T.K.RAMACHANDRAN
}

Coconut Research Station, Tamil Nadu Agricultural University, Veppankulam 614 906, Tamil Nadu, India

\begin{abstract}
A field experiment was carried out in Thanjavur District, Tamil Nadu, India with six green manure crops to study their ability to grow and establish in the coconut basin and to evaluate their effect on nut yield. Among the crops tested, Desmodium tortuosum was found to be the best producing $12.8 \mathrm{~kg}$ of green leaf matter per basin followed by cowpea (Vigna unguiculata) and sunhemp (Crotolaria juncea). The dry matter production was also found to be superior in Desmodium compared to others. Incorporation of Desmodium added $250 \mathrm{~g}$ of $\mathrm{N}$ per crop per basin which was the highest. In situ cultivation and incorporation of Desmodium and sunhemp significantly increased the nut yield of coconut.
\end{abstract}

\section{INTRODUCTION}

Maintenance of soil organic matter is very essential for the successful growth and yield of crops. Coconut is predominantly grown in sandy soils which often lack adequate quantity of organic matter. In tropical soils the organic matter content has to be enhanced regularly in view of the rapid oxidation and exhaustion. It has been observed that most coconut growing soils are deficient in one or more nutrients. Indian soils are usually very poor in organic matter and nitrogen (Sumathykuttyamma, 1977). The deficiency of organic matter co-exists .with the deficiency of nitrogen which limits the performance of coconut palms. The organic matter status of the soil can be maintained by the addition of green leaves, compost or farm-yard manure (FYM). However, in many coconut gardens, farmers are unable to apply the required quantities of compost or FYM because of inadequate supply. Hence, cultivation of green manure crops in situ and their incorporation were considered to be a viable alternative. This is practised by the farmers as it is the most convenient and economic method of enhancing the organic matter status in the soil. Leguminous green manure crops improve the soil structure and nitrogen status of the soil. In addition, they aid in releasing plant nutrients, reducing leaching, regulating soil temperature, and enhance the activity of soil microflora. Several leguminous green manure crops have been tested in coconut gardens in the past. The suitability of the green manure crop in the coconut basin management depends on the climatic and soil characteristics in a particular region. It is, therefore, essential to identify the ideal green manure crop for a particular location. This paper describes studies on evaluation of green manure crops - for coconut basin management, carried out at the Coconut Research Station, Veppankulam, Thanjavur District, Tamil Nadu, India.

- Present address: Sugarcane Research Station, Sirugamani 639115, Tamil Nadu, India. 


\section{Effects of Cultivation and Incorporation of Green Manure Crops}

\section{MATERIALS AND METHODS}

Six green manure crops, hedge lucerne (Desmanthus virgatus), green leaf desmodium (Desmodium tortuosum), Cowpea (Vigna unguiculata), Tephrosia (Tephrosia purpurea), daincha (Sesbania aculeata), and sunhemp (Crotolaria juncea) were raised in coconut basins of $1.8 \mathrm{~m}$ radius. The palms were 25 -years old of the variety 'East Coast Tall'. Five crops of each green manure species were raised during the course of the study period of three years as detailed below:

$\begin{array}{ll}\text { First Crop } & \text { Sown on 19 June, 1985 - } \\ \text { Second crop } & \text { Sown on 18 December, 1985 - } \\ \text { Third crop } & \text { Sown on 14 August, 1986 - } \\ \text { Fourth crop } & \text { Sown on 31 December, 1986 - } \\ \text { Fifth crop } & \text { Sown on 26 August, 1987 - }\end{array}$

The green manure crops were incorporated in situ at their flowering stage. In the case of cowpea, Tephrosia, daincha and sunhemp incorporation was 55 days after sowing while in Desmodium and Desmanthus it was 75 days after sowing. The coconut palms received uniform manurial and irrigation schedules. A manurial schedule of 560 g N, $325 \mathrm{~g} \mathrm{P}_{2} \mathrm{O}_{5}$ and $1200 \mathrm{~g} \mathrm{~K}_{2} \mathrm{O}$ per palm per year was followed. The treatments were replicated nine times with one palm per plot in a Randomized Block Design. The height of the green manure plants and weight were recorded in five plants at random from each replicate. Five plants were uprooted and the height was measured from the base of the stem to the top most leaf and the weight was, recorded for the whole plant including the roots. At flowering stage, the crop was harvested and the fresh weight was recorded. Dry matter production was estimated by sun-drying the harvested crop to constant weight. Two basins per treatment were used for estimation of dry matter production. After weighing the dry matter, it was incorporated into the respective basin. The nodulation status was also assessed at flowering, in five plants from each basin. Nitrogen in plant top was estimated using the micro-kjeldahl method after drying the samples at $70^{\circ} \mathrm{C}$ for four days. The green matter obtained was incorporated into the respective basins.

\section{RESULTS AND DISCUSSION}

The time trend of growth in terms of plant height and weight revealed that sunhemp was the tallest among all the crops studied at all stages of growth (Table 1). The mean fresh weight per plant at flowering stage was found to be the highest in Desmodium, followed by daincha and cowpea. The growth and development of Desmodium were generally good under coconut, indicating its shade-tolerant nature.

All the green manure crops were evaluated for their green matter yield for all five sowings (Table 2) The highest mean green matter yield was observed in Desmodium $(12.8 \mathrm{~kg} / \mathrm{basin})$ followed by cowpea $(7.59 \mathrm{~kg} / \mathrm{basin})$ and sunhemp $(7.46$ $\mathrm{kg} / \mathrm{basin}$ ). The dry matter production was also found to be superior in Desmodium, compared to the others. The nodule formation was highest in daincha. The highest $\mathrm{N}$ content of $44.5 \mathrm{mg} / \mathrm{g}$ was observed in sunhemp, followed by cowpea and Desmodium (Table 3). Of the green manure crops, Desmodium incorporated nearly $250 \mathrm{~g} \mathrm{~N}$ per basin, closely followed by sunhemp.

The effect of in situ cultivation and incorporation of different green manure crops in coconut basins on the yield of coconut is presented in Table 4. The mean nut yield of 3.5 years of post-treatment period (January, 1985 - June, 1988) was subjected to 


\section{H VIJAYARAGAVAN and T.K.RAMACHANDRAN}

covariance analysis considering the pre-treatment yield of two years 1983-84 as an independent variable over which the post-treatment yield of 3.5 years was regressed upon (Panse \& Sukhatme, 1967).

Table 1 - Plant height and fresh weight of green manure crops under coconut shade (mean of five crops)

\begin{tabular}{|c|c|c|c|c|c|c|c|c|}
\hline $\begin{array}{l}\text { Green } \\
\text { Manure } \\
\text { Crop }\end{array}$ & $\begin{array}{l}\text { Plant } \\
15 \\
\text { days }\end{array}$ & $\begin{array}{l}\text { height } \\
30 \\
\text { after }\end{array}$ & $\begin{array}{l}45 \\
\text { sowing) }\end{array}$ & $\begin{array}{l}(\mathrm{cm}) \\
\text { At } \\
\text { Flowering }\end{array}$ & $\begin{array}{c}\text { Plant } \\
15 \\
\text { (days }\end{array}$ & $\begin{array}{l}\text { weight } \\
30 \\
\text { after }\end{array}$ & $\begin{array}{l}45 \\
\text { sowing }\end{array}$ & $\begin{array}{l}\text { (g/plant) } \\
\text { At } \\
\text { Flowering }\end{array}$ \\
\hline Desmanthus & 4.9 & 18.3 & 22.8 & 29.5 & 0.17 & 0.19 & 0.44 & 1.93 \\
\hline Desmodium & 5.7 & 22.2 & 28.8 & 53.1 & 0.32 & 3.25 & 4.50 & 10.24 \\
\hline Cowpea & 19.3 & 23.5 & 30.2 & 34.8 & 0.32 & 3.10 & 4.48 & 8.85 \\
\hline Tephrosia & 4.4 & 14.3 & 16.6 & 22.8 & 0.27 & 1.10 & 1.43 & 5.60 \\
\hline Daincha & 15.2 & 27.1 & 39.9 & 57.4 & 0.29 & 2.10 & 3.38 & 9.48 \\
\hline Sunhemp & 36.3 & 55.0 & 85.1 & 103.0 & 0.36 & 2.18 & 3.04 & 8.00 \\
\hline SE $( \pm)$ & 5.1 & 5.9 & 10.1 & 12.0 & 0.03 & 0.48 & 0.67 & 1.26 \\
\hline $\begin{array}{l}\text { LSD } \\
(P=0.05)\end{array}$ & 12.7 & 14.9 & 25.3 & 29.9 & 0.07 & 1.20 & 1.68 & 3.17 \\
\hline
\end{tabular}

Table 2 - Yield of green matter and dry matter by green manure crops under coconut shade (mean of five crops)

\begin{tabular}{lcc}
\hline $\begin{array}{l}\text { Green Manure } \\
\text { Crop }\end{array}$ & $\begin{array}{c}\text { Green Matter Yield } \\
(\text { Kg/basin })\end{array}$ & $\begin{array}{c}\text { Dry Matter Yield } \\
(\text { Kglbasin })\end{array}$ \\
\hline Desmanthus & 1.70 & 1.03 \\
Desmodium & 12.80 & 7.05 \\
Cowpea & 7.59 & 5.17 \\
Tephrosia & 2.58 & 5.68 \\
Daincha & 4.73 & 2.46 \\
Sunhemp & 7.46 & 4.62 \\
SE ( \pm$)$ & 1.66 & 0.95 \\
LSD (P=0.05) & 4.15 & 2.38 \\
\hline
\end{tabular}

Table 3: Nodule status, $N$ content and $N$ incorporation by green manure crops in the coconut basin.

\begin{tabular}{lccc}
\hline $\begin{array}{l}\text { Green manure } \\
\text { crop }\end{array}$ & $\begin{array}{l}\text { Nodules } \\
\text { (no./plant) }\end{array}$ & $\begin{array}{l}\text { N content } \\
(\mathrm{mg} / \mathrm{g})\end{array}$ & $\begin{array}{l}\text { N incorpo- } \\
\text { ration }(\mathrm{g} / \text { basin })\end{array}$ \\
\hline Desmanthus & 2 & 28.6 & 29.5 \\
Desmodium & 5 & 35.3 & 248.9 \\
Cowpea & 14 & 38.3 & 198.0 \\
Tephrosia & 3 & 24.6 & 41.3 \\
Daincha & 16 & 37.0 & 91.0 \\
Sunhemp & 7 & 44.5 & 205.6 \\
SE $( \pm)$ & 2.4 & 2.9 & 38.4 \\
LSD $(\mathrm{P}=0.05)$ & 5.9 & 7.3 & 95.9 \\
\hline
\end{tabular}

It is evident that Desmodium and sunhemp have significantly increased the nut yield of coconut. The coconut palms where Desmodium and sunhemp were incorporated registered 97.4 and 93.2 nuts respectively, compared to 68.6 
Effect of Cultivation and Incorporation of Green Manure Crops

Table 4. Effect of in situ cultivation and incorporation of green manure crops on the yield of coconut

\begin{tabular}{|c|c|c|}
\hline \multirow{2}{*}{$\begin{array}{l}\text { Green manure } \\
\text { crop }\end{array}$} & \multicolumn{2}{|c|}{ Mean nut yield (nuts/palm/year) } \\
\hline & $\begin{array}{l}\text { Pre-treatment period } \\
\quad(1983-84)\end{array}$ & $\begin{array}{l}\text { Post-treatment period } \\
\text { (Jan 1985-June 1988) }\end{array}$ \\
\hline Control & 55.1 & 68.6 \\
\hline Desmanthus & 57.0 & 75.4 \\
\hline Desmodium & 61.2 & $97.4^{*}$ \\
\hline Cowpea & 64.3 & 71.6 \\
\hline Tephrosia. & 56.6 & 76.1 . \\
\hline Daincha & 60.8 & 76.2 \\
\hline Sunhemp & 57.7 & $93.2^{*}$ \\
\hline$S E( \pm)$ & & 8.1 \\
\hline $\operatorname{LSD}(P=0.05)$ & & 16.3 \\
\hline
\end{tabular}

* significant at $5 \%$ level.

nuts/palm/year in the control. The improvement in yield is likely to be due to the addition of nitrogen through the green manure crop and improvement of organic matter in the soil. It is recorded that the application of organic matter like coconut pith, forest leaves and cattle manure had considerably improved the growth and flowering in coconut (Anon, 1980). The yield improvement in coconut where Desmodium had been incorporated is explained by the increased production of female flowers, resulting in enhanced nut yield. Thomas and Shantaram (1984) observed beneficial effects of in situ incorporation of green manure in coconut and stressed the importance of green manuring in improving the activity of soil microflora and suppression of soil-borne plant pathogens which might be beneficial for increased coconut production.

These experiments demonstrate the possibility of in situ cultivation of green manure crops in coconut basins and their incorporation into the soil to provide nitrogen and to enhance the organic matter status of the soil. Under the conditions of Thanjavur district (Tamil Nadu), Desmodium produced profuse foliage under the shade of coconut and proved to be a satisfactory green manure crop to provide additional nitrogen and organic matter.

\section{ACKNOWLEDGEMENTS}

The authors are thankful to Dr. S. Chelliah, Director, Tamil Nadu Rice Research Institute, Aduthurai for his kind encouragement in the study.

\section{REFERENCES}

Anonymous (1980) Annual Report for 1979. Central Plantations Crops Research Institute, Kasaragod, Kerala, India. p.48.

Panse, V. G. \& P. V. Sukhatme (1967) Statistical methods for agricultural workers. ICAR, New Delhi. p.361.

Sumathykuttyamma, B (1977) Soil organic matter - the need for its enrichment. Indian Coconut Journal 8: 1-2.

Thomas, G. V. \& M. V. Shantaram (1984) In situ cultivation and incorporation of green manure legumes in coconut basins. Plant and Soil 80: 373-380. 